\title{
Alpha-1 Antitrypsin Deficiency
}

National Cancer Institute

\section{Source}

National Cancer Institute. Alpha-1 Antitrypsin Deficiency. NCI Thesaurus. Code C84397.

A genetic disorder characterized by decreased alpha-1 antitrypsin activity in the lungs and blood and deposition of alpha-1 antitrypsin protein in the hepatocytes. These abnormalities result from defective production of alpha- 1 antitrypsin and lead to the development of emphysema, cirrhosis, and liver failure. 